\title{
中国における労働移動と都市労働市場の分断化： 出稼ぎ労働者・都市戸籍住民間の所得格差に関する実証分析
}

\author{
馬 欣欣
}

論文要旨：中国では市場経済期に入って農村と都市間の労働移動に伴う都市労働市場の分断化の問 題が深刻となっている．本稿では部門間格差（都市正規と都市非正規，出稼ぎ正規と出稼ぎ非正規間 の所得格差), および部門内格差 (都市正規と出稼ぎ正規, 都市非正規と出稼ぎ非正規間の所得格差) の要因に関する実証分析を行った。計量分析の結果，都市労働市場が戸籍および就業部門により分断 されていることが示された.

[キーワード : 非正規部門, 出稼ぎ労働者, 所得格差, 労働市場の分断化]

\section{1 はじめに}

中国では，計画経済期（1949～77年）に都市戸 籍と農村戸籍を明確に分ける戸籍制度が実施され た後，農村と都市の労働市場が分断され，政府が 労㗢力を統一的に調達寸る場合を除いて，農村か ら都市への労働移動が禁止された。しかし，市場 経済期（1978年〜現在）になると，戸籍制度の規 制緩和に伴って出稼ぎ労働者 ${ }^{1)}$ が増加した. 中国 農業部の統計調査によれば，2004年には出稼ぎ労 働者は総計 1.3 億人で, 都市産業における労働者数 2. 2 億人の $59 \%$ を占めることとなった（岳・黄, 2008). World Bank (1996), Lees (1997), 蔡・王 （1999）は, 労働移動が中国の経済発展にプラスの 影響を与えることを示している.

一方, 中国の都市において, 労働移動の増加と ともに非正規部門 2) での就業者が増加しており, 労働市場の分断化 ( LMS, Labor Market Segmentation) の問題 ${ }^{3)}$ が深刻化している (Knight, Song and Jia, 1999; Meng, 2001; 厳, 2008; 馬, 2008a). 都市労働市場の分断化の問題が生じた主 な要因は，中国特有の制度的要因によって都市労 働市場が多重構造となったことにあると考えられ る. 1990年代以後, 市場化を目指寸経済改革が促 進されたが, 政府がコントロールする国有企業 (正 規部門）の雇用・賃金制度，農村労働者と都市戸 籍住民を差別する戸籍制度が依然として労働者の
就業および貨金所得に大きな影響を与えている (蔡・白, 2006). そのため, 労働生産性が同じで も, 戸籍（都市戸籍住民と出稼ぎ労働者）および 就業する部門（正規部門と非正規部門）によって 賃金所得が異なると考えられる。つまり都市労働 市場は，正規部門と非正規部門，および同一部門 における都市戸籍を持つ労働者と農村戸籍を持つ 労働者が同時に存在しているという多重構造とな っており, 労働市場は各グループにより分断され ていることがうかがえる，中国における労働移動 の問題を解明するため, 都市労働市場の多重構造 を考慮したうえで, 労働市場の分断化に関する実 証分析を行うことは重要な課題となっている.

次に中国における都市労働市場の分断化に関す る実証研究を概観する。 この課題については, 出 稼ぎ労働者と都市戸籍住民 ${ }^{4}$ 間, および出稼ぎ労 働者における正規者と非正規者間の所得格差に関 する計量分析が行われた ${ }^{5)}$. Knight, Song and Jia （1999）は1995年の4都市（北京市, 深セン市, 武 漢市，蘇州市）における企業調査の個票データを 用いて分析し, 都市戸籍住民と出稼ぎ労働者の間 に所得格差が存在し, 両者の所得構造が異なるこ とを指摘している．Meng（2001）は1995年山東省 済南市で実施された調查の個票データを利用し,

Oaxaca（1973）要因分解モデルを用いた分析を行 った結果, 出稼ぎ労働者に関して正規者, 非正規 者, 自営業者の各グループ間の所得格差が存在し, 
各グループ間の所得格差に与える影響はいずれも 労㗢生産性の差異以外の要因が労働生産性の差異 より大きいことを明らかにしている. 佐藤 (2004) は1999年中国都市出稼ぎ労働者所得調査の個票デ 一タを用い, 出稼ぎ雇用者之出稼ぎ自営業者の所 得関数を推定し，両者の賃金構造が異なることを 示している. 厳 (2008) は上海市を対象とした $4 つ$ の調査の個票データを用い，地元労働者と非地元 労働者の賃金関数を推定し，両者の賃金構造が異 なり，上海市で労働市場の二重構造が存在するこ とを指摘している．馬（2008a）は2002年中国出稼 ぎ労働者所得調査の個票データ (以下では MCHIP 2002 と呼ぶ）を利用し，所得関数に基づいて Oaxaca（1973）要因分解の分析を行い，都市正規 と都市非正規, 都市正規と出稼ぎ非正規, 都市非正 規と出稼ぎ非正規の 3 つのグループ間で所得格差 が存在し, 労働生産性の差異以外の要因が各グル 一プ間の所得格差の主な要因であり, 都市労働市 場が分断されていることを示している.

しかし，上記の中国に関する先行研究ではいく つかの問題点が残されている. 第 1 に, 分析対象 の範囲である．Knight, Song and Jia（1999）， Meng （2001）は中国のごく一部の省・市の労働者を分析 対象としたため, 全国の状況を把握できていない. 第 2 に, グループ分類の問題である. 出稼ぎ労働 者と都市戸籍住民間の所得格差は，同一部門（正 規あるいは非正規）における各グループ（都市戸 籍住民，出稼ぎ労働者）間の所得格差 ${ }^{6)}$ (以下で は,「部門内格差」と呼ぶ) および同一グループ (都 市戸籍住民あるいは出稼ぎ労働者）における部門 間（正規と非正規間）の所得格差 ${ }^{7)}$ (以下では, 「部門間格差」と呼ぶ）の 2 種類に分けられる. 前 者は戸籍制度による分断化の問題に関連し, 後者 は就業する部門（正規部門，非正規部門）による 分断化の問題に関連する. したがって, 分断化の 問題を正確に理解寸るためには，都市正規，出稼 ぎ正規，都市非正規，出稼ぎ非正規の 4 つのグル ープに分けて各グループ間の所得格差に関する分 析を行う必要がある。しかし, 現在までの先行研 究では, 4 つのグループ間の所得格差に関する実 証分析が行われておらず，とくに正規部門内部の 分断化に関する実証分析が行われていない。その ため，都市労働市場の分断化に関する具体的な状
況は明確ではない，第 3 に，計量分析の手法の問 題である. 先行研究では, 所得関数を OLS により 推定しているため, 結果に就業形態の選択に伴う 標本の非ランダム性の問題が残っている。また, Oaxaca（1973）モデルを用いた要因分解の結果に インデックス問題が存在していると考えられる. 第 4 に, 市場移行期の中国労働市場は従来の計画 経済期の社会・経済制度の影響を受けており, 党 員であるかどうかという政治資本が労働者の就業 及び賃金所得に影響を与えていると考えられる ${ }^{8)}$. しかし，上記の先行研究で政治資本を考慮した分 析が少ない.

本稿では先行研究の問題点を踏まえ, 実証分析 を行う. 本稿の主な特徽は以下の 4 点である. 第 1 に，全国の代表的な地域で行った大規模な2002年 中国都市出稼ぎ労働者所得調查および2002年中国 都市戸籍住民所得調查（以下では UCHIP 2002 と 呼ぶ）の個票データを用いて実証分析を行い，労 働市場の分断化の全体像を把握することができる. 第 2 に, 先行研究とは異なり, 本稿では都市正規, 出稼ぎ正規, 都市非正規, 出稼ぎ非正規の 4 つの グループに分けて, 部門内格差と部門間格差に関 する分析をそれぞれ行う。本稿は，正規部門内の 分断化に関するはじめての実証研究である. 第 3 に, 本稿では標本の非ランダム性の問題に対応す るため, OLS のみならず，多項プロビットモデル (Ashford and Sowden, 1970; Amemiya, 1981; Greene, 2003) を用いた Heckman（1976）に基づく 二段階の推定法 (Heckman's two-step estimator，以 下では, 「二段階の推定法」と略称する場合もある） による所得関数も推定する. また, Oaxaca（1973） モデルのインデックス問題に対応寸るため, 中国 に関する先行研究で用いられなかった Oaxaca and Ransom（1994）の要因分解モデルを用いて実証分 析を行う。第 4 に，人的資本と政治資本を含む分 析を行い, 政治資本の影響を検討することも，本 稿のもう一つの大きな特徴である.

本稿の構成は以下の通りである. 第 2 節で個票 データから観察された所得格差および所得分布の 状況について述べる. 第 3 節では計量分析の枠組 みについて説明し，第 4 節ではその枠組みに基づ く計量分析を行い, 得られた分析結果について説 明する．最後に結論と政策提言をまとめる. 
表1 出稼ぎ労働者と都市戸籍住民の所得格差の状況

\begin{tabular}{|c|c|c|c|c|c|c|c|c|}
\hline & \multicolumn{2}{|c|}{ 都市戸籍住民 } & \multicolumn{2}{|c|}{ 出稼ぎ労働者 } & \multicolumn{2}{|c|}{ 部門内格差 } & \multicolumn{2}{|c|}{ 部門間格差 } \\
\hline & $\begin{array}{c}\text { 正規 } \\
\text { A } \\
\text { (元/時間) }\end{array}$ & $\begin{array}{c}\text { 非正規 } \\
\text { B } \\
\text { (元/時間) }\end{array}$ & $\begin{array}{c}\text { 正規 } \\
\mathrm{C} \\
\text { (元/時間) } \\
\end{array}$ & $\begin{array}{c}\text { 非正規 } \\
\text { D } \\
\text { (元/時間) }\end{array}$ & $\begin{array}{l}\mathrm{C} / \mathrm{A} \\
(\%) \\
\end{array}$ & $\begin{array}{l}\mathrm{D} / \mathrm{B} \\
(\%) \\
\end{array}$ & $\begin{array}{l}\mathrm{B} / \mathrm{A} \\
(\%) \\
\end{array}$ & $\begin{array}{l}\mathrm{D} / \mathrm{C} \\
(\%) \\
\end{array}$ \\
\hline 学歴別 & & & & & & & & \\
\hline 短大以上 & 7.458 & 5.257 & 5.835 & 4.185 & 78.3 & 79.5 & 70.5 & 71.6 \\
\hline 高校 & 6.293 & 3.940 & 3.721 & 3.685 & 59.1 & 93.7 & 62.6 & 99.2 \\
\hline 専門学校 & 5.441 & 3.671 & 3.700 & 3.826 & 68.0 & 104.4 & 67.5 & 103.5 \\
\hline 中学 & 4.771 & 3.345 & 2.823 & 3.097 & 59.1 & 92.5 & 70.2 & 109.9 \\
\hline $\begin{array}{l}\text { 小学以下 } \\
\text { 年齢別 }\end{array}$ & 4.153 & 2.377 & 2.202 & 2.424 & 53.0 & 101.7 & 57.3 & 110.0 \\
\hline $20 \sim 29$ 歳 & 4.896 & 3.268 & 3.418 & 3.021 & 69.8 & 92.4 & 66.7 & 88.3 \\
\hline $30 \sim 39$ 歳 & 5.787 & 3.658 & 3.045 & 3.062 & 52.5 & 83.6 & 63.2 & 100.7 \\
\hline $40 \sim 49$ 歳 & 6.372 & 3.721 & 3.149 & 3.418 & 49.5 & 91.9 & 58.4 & 108.6 \\
\hline $\begin{array}{l}50 \sim 59 \text { 歳 } \\
\text { 政治地位別 }\end{array}$ & 7.101 & 4.440 & 2.226 & 2.421 & 31.4 & 54.5 & 62.5 & 108.5 \\
\hline 党員 & 7.271 & 4.857 & 4.184 & 4.013 & 50.7 & 83.7 & 66.9 & 95.9 \\
\hline 非党員 & 5.579 & 3.574 & 3.009 & 3.032 & 47.3 & 74.3 & 64.0 & 100.7 \\
\hline
\end{tabular}

出所 : UCHIP 2002および RMCHIP 2002より計算.

\section{2 出稼ぎ労働者, 都市戸籍住民における 所得格差および所得分布の状況}

\section{1 各要因別にみた所得格差の状況}

表 1 で各要因別にみた所得格差の状況をまとめ ている，正規部門と非正規部門において，出稼ぎ 労働者の所得が都市戸籍住民の所得に占める割合 を部門内格差の指標として用いている。また, 出 稼ぎ労働者, 都市戸籍住民において, 非正規労働 者の所得が正規労働者の所得に占める割合を部門 間格差の指標として用いている.これらの数值が 低くなるほど，部門内格差と部門間格差が大きく なることを意味する.クロス集計の結果によれば, 以下のことが示されている.

第 1 に，正規部門と非正規部門において，いず れも平均所得は出稼ぎ労働者が都市戸籍住民より 低い. 部門内格差が存在し, 中国の都市労働市場 は労働者が持つ戸籍により分断されていることが 見て取れる.

第 2 に, 部門間格差の状況は出稼ぎ労働者, 都 市戸籍住民により異なっている，都市戸籍住民に おいて平均所得は正規者が非正規者より高い。一 方, 出稼ぎ労働者の場合, 学歴が低く, 年齢が高 いグループ，および非党員のグループにおいて， 平均所得は正規者が非正規者より低い。また、各 要因別のグループにおいて，いずれも正規者と非 正規者間の所得格差は都市戸籍住民が出稼ぎ労働 者より大きい.

\section{2 所得分布の状況}

図 1 で, 都市正規, 出稼ぎ正規, 都市非正規, 出稼ぎ非正規の各グループにおける所得の Kernel 密度分布と正規分布を表している. まず所得分布 の形状を検討する．各グループにおいて，いずれ も所得分布がほぼ正規分布となっており, Kernel 密度分布と正規分布の差異が小さいことが見て取 れる，次に所得の大きさをみれば，都市正規の場 合, 所得 (対数值) が1.8に集中する一方, 都市非 正規, 出稼ぎ正規, 出稼ぎ非正規の場合, 所得 (対 数值) が0.8〜1.0に集中することがわかる.また, 平均所得は都市正規が最も高いことが見て取れる. さらに所得対数の分散は, 出稼ぎ正規が都市正規, 都市非正規, 出稼ぎ非正規よりやや小さい傾向に ある。

以上のクロス集計の結果により, 部門内格差, 部門間格差が存在すること, および都市正規, 出 稼ぎ正規, 都市非正規, 出稼ぎ非正規の所得分布 がそれぞれ異なることが示された. 次なる課題は, 人的資本と政治資本がどの程度各グループ間の所 得格差に影響を与えるか, また労働生産性が同じ である場合, 各グループ間の所得格差が存在する かなどの問題を解明することである，その目的の ために, 以下では各グループ間の所得格差に関す る計量分析を行う。 
図1＼cjkstart出稼ぎ労働者と都市戸籍住民の所得分布の状沉
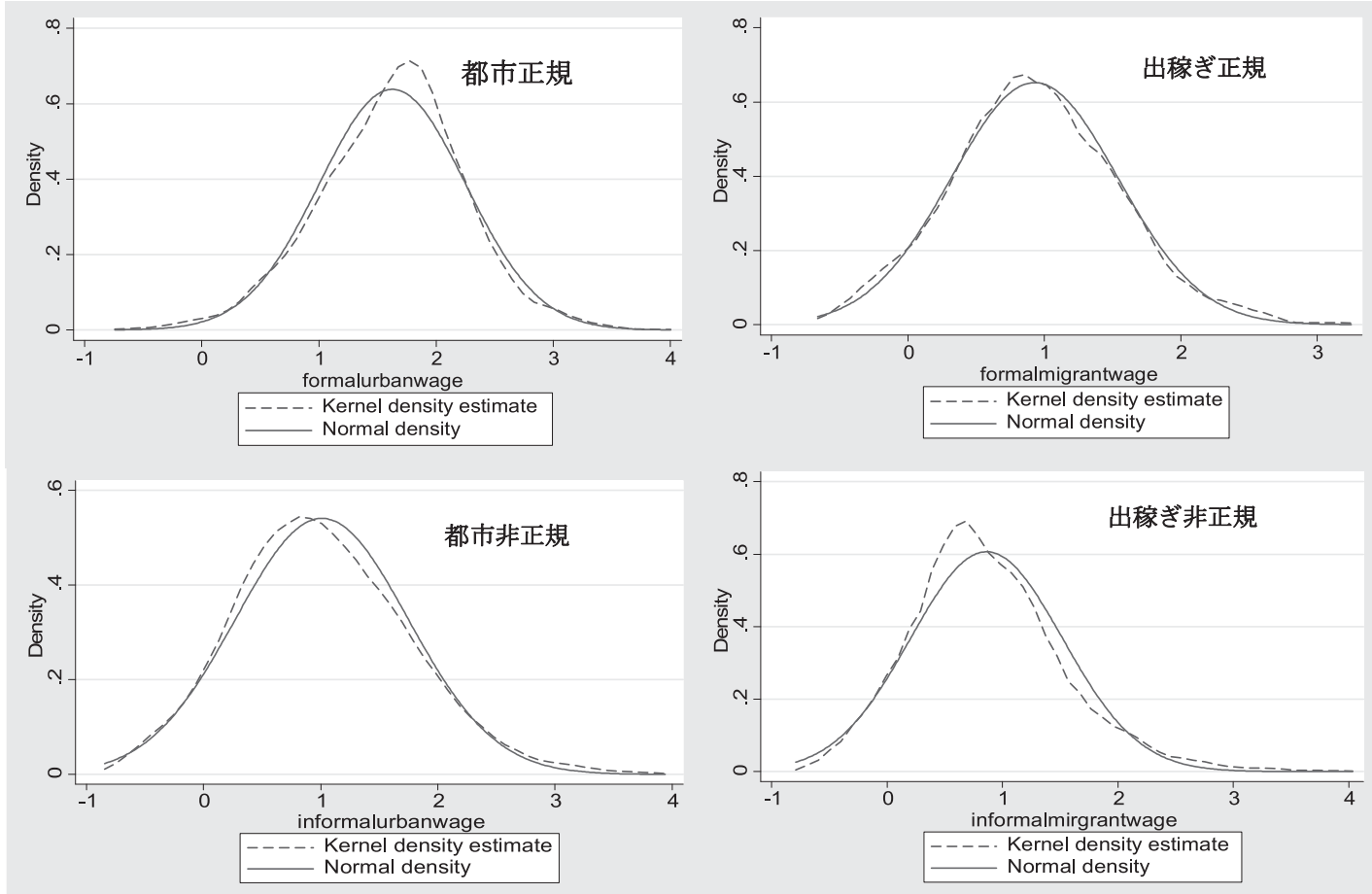

注）横軸の值は時間当たり所得対数を示し，縦軸の数值は頻度を示す.

出所 : 表 1 と同じ.

\section{3 計量分析の枠組み}

\section{1 推定モデル}

計量分析の手順は以下の通りである. 第 1 に, 多項ロジットモデル（multinomial logit model）を 用いて就業形態の選択（正規就業，非正規就業， 非就業）に関する分析を行い，就業形態の選択の 決定要因を検討する. 第 2 に, 所得関数を推定し, 各グループの所得構造を明らかにする. 第 3 に, Oaxaca and Ransom（1994）の要因分解モデルを用 いて各グループ間の所得格差に関する要因分解の 分析を行う.

計量分析を行う際に, 以下の問題を考慮するこ とが必要である. 第 1 に, 所得関数を推定する際 に, 就業形態の選択によるサンプルの非ランダム 性の問題が存在する可能性がある。この問題を解 決するため, 二段階の推定法による所得関数を推 定する. 具体的に, 第一段階で多項プロビットモ デル (multivariate probit model) ${ }^{9)}$ を用いてセレク ション修正項（逆ミルズ比）を算出する. 第二段 階で逆ミルズ比（inverse Mill's ratio）を OLS 所得
関数に加え, サンプル・セレクション・バイアス を修正した所得関数の推定を行う. 第 2 に, 二段 階の推定で, 識別問題に対応寸るため, 就業形態 に関する多項プロビット分析では, 所得関数には 含まれない変数 (年齢, 年齢の 2 乗, 地元戸籍ダ ミーの変数）を説明変数として用いている. 以下 では各推定モデルを定式化する.

まず就業形態の選択に関する多項ロジットモデ ルは（1）式，(2) 式で示す ${ }^{10) . ~}$

$$
\begin{array}{r}
I_{s i}^{*}=\gamma_{s} z_{s i}+\varepsilon_{s i} \quad(i=1,2 \cdots, N) \\
I=s \quad \text { if } \gamma_{s} z_{s}-\gamma_{j} z_{j}>\varepsilon_{j}-\varepsilon_{s} \quad(j \neq s) \\
\operatorname{Pr}\left(\varepsilon_{s}<\gamma_{s} z_{s}\right)=\operatorname{Pr}(I=s)=\frac{\exp \left(\gamma_{s} z_{s}\right)}{\sum_{J=1}^{M} \exp \left(\gamma_{J} z_{J}\right)} \\
(J=1, \cdots s \cdots M)
\end{array}
$$

$Z$ : 教育年数, 年齢, 年齢の 2 乗, 党員ダミー, 転職ありダミー, 健康ダミー, 男性ダミー, 既婚ダミー，地元戸籍ダミー

（1）式，（2）式では, 添字 $i$ は労働者個人 
$(i=1.2 \cdots, N), J=1, \cdots s \cdots M$ は就業形態の集合, $z_{s i}$ は労働者 $i$ が就業形態 $s$ を選択寸ることに影 響を与える各要因, $\gamma$ は $z$ の推定係数, $\varepsilon$ は選択 関数の誤差項をそれぞれ示す． $I^{*}$ は選択集合から ある就業形態 $s$ を選択する確率である. 労働者 $i$ は自分の効用を最大化するため, $s$ を選択する. $\gamma$ の推定值を用いて，就業形態の選択の決定要因を 検討することができる.

次に所得関数について説明する。（3）式は所得 関数の OLS（最小 2 乗法）推定式である.

$\ln$ income $_{i}=\beta X_{i}+u_{i}$

$X$ : 教育年数, 経験年数, 経験年数の 2 乗, 党 員ダミー，転職ありダミー，健康ダミー，男性 ダミー，既婚ダミー，産業ダミー

(3)式において， lnincome は時間当たり所得 の対数值, $X$ が所得に影響を与える各要因, $\beta$ は $X$ の推定係数, $u$ は誤差項を示寸.

労働者 $i$ が多項の選択肢（例えば，正規就業， 非正規就業，非就業）を含む選択集合からある就 業形態 $s$ （例えば，正規就業）を選択する．労働 者 $i$ の所得 $\ln$ income $_{s i}$ については, $s$ を選択した 場合しかその值が観察できない. OLS ではそうし た就業形態の選択を考慮していないため, 分析結 果に標本の非ランダム性の問題が残される (Heckman, 1976). 就業形態の選択からくるサン プル・セレクション・バイアスを修正するため, 二段階の推定を行うことが必要である. 具体的に, 第一段階で就業形態の選択に関する多項プロビッ 卜分析を行い，逆ミルズ比を求める. 第二段階の OLS 推定に逆ミルズ比を加えることで, OLS 推定 值のバイアスを修正する. 所得関数の二段階推定 法の推定式は，（4）式から（8）式までで示す.

労㗢供給の主体均衡モデルによれば, 労働者 $i$ は 自分の効用を最大化するため, $s$ を選択する. 就業 形態は具体的に正規就業（ full），非正規就業 ( part)，非就業（no）で表示すると，各選択肢 から得られる効用を（4）式で示すことができる.

$$
\begin{aligned}
& U_{\text {fulli }}=\gamma_{\text {full }} z_{\text {fulli }}+\varepsilon_{\text {fulli }} \\
& U_{\text {parti }}=\gamma_{\text {partl }} z_{\text {parti }}+\varepsilon_{\text {parti }} \\
& U_{n o i}=\gamma_{n o} z_{n o i}+\varepsilon_{\text {noi }}
\end{aligned}
$$

（4）式では, $U_{\text {full }}, U_{\text {partl }}, U_{n o}$ は正規就業 ( full ), 非正規就業 ( part), 非就業 (no) の それぞれの効用関数， $z$ は就業形態の選択に影響 を与える各要因, $\gamma_{\text {full }}, \gamma_{\text {part }}, \gamma_{n o}$ は各推定係 数, $\varepsilon_{\text {full }}, \varepsilon_{\text {part }}, \varepsilon_{n o}$ は各誤差項を示す. $\varepsilon_{\text {full }}$, $\varepsilon_{\text {part }}, \varepsilon_{n o}$ はお互いに分散が異なる相関を持ち, つまり（5）式で示されるように，共分散のマドリ ックス (covariance matrix, $\sum$ で示す) が存在す る.ここで, 就業形態を選択寸る確率が正規分布 であることを仮定し，多項プロビットモデルを用 いて就業形態を選択する確率に関する分析を行う. 確率の累積分布関数 $(\Phi(\cdot))$ は $(6)$ 式, 密度関 数 $(\phi(\cdot))$ は (7) 式で示す.

$\sum=\operatorname{cov}(\varepsilon)$

$\left(\begin{array}{llc}\sigma_{\text {full }}^{2} & \sigma_{\text {full,part }} & \sigma_{\text {full,no }} \\ \sigma_{\text {full,part }} & \sigma_{\text {part }}^{2} & \sigma_{\text {part }, n o} \\ \sigma_{\text {full.no }} & \sigma_{\text {part }, n o} & \sigma_{n o}^{2}\end{array}\right)$

$\Phi(z)=\int_{-\infty}^{z_{J}} \int_{-\infty}^{z_{J-1}} \cdots \int_{-\infty}^{z_{1}} \phi(z) d z_{1} \cdots d z_{J-1} d z_{J}$

$\phi(z)=\frac{1}{(\sqrt{2 \pi})^{J-1} \mid \Sigma^{1 / 2}} \exp \left(-\frac{1}{2} \varepsilon^{\prime} \Sigma^{-1} \varepsilon\right)$

第一段階の推定（就業形態の選択関数）の誤差 項 $\varepsilon_{\text {full }}, \varepsilon_{\text {part }}, \varepsilon_{\text {no }}$ が正規分布であれば, $E(u \mid \varepsilon<=\gamma z=-\sigma 2 \phi(\gamma z) / \Phi(\gamma z)$ という関係が得 られ, 逆ミルズ比 $(\lambda=\phi(\gamma z) / \Phi(\gamma z))$ を算出する ことができる. 逆ミルズ比を第二段階の OLS 所得 関数に加えることで, 所得関数の新しい誤差項の 期待值がゼロとなり, 就業形態の選択によるサン プル・セレクション・バイアスを修正することが できる，このように修正した所得関数は，（8）式 で示す.

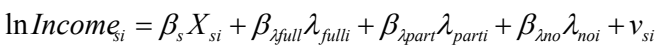

（8）式では， $X$ は所得に影響を与える各要因, $\lambda_{\text {full }}, \lambda_{\text {part }}, \lambda_{\text {no }}$ は正規就業, 非正規就業, 非 就業の選択から計算した逆ミルズ比, $\beta, \beta_{\lambda f u l l}$, $\beta_{\lambda \text { part }}, \beta_{\lambda n o}$ は各推定係数, $v$ は新しい誤差項を それぞれ示す. 本稿では（8）式を用いて各グルー プの所得関数を推定し， $\beta$ を用いて各グループの 
所得構造を明確にする。 また推定結果で $\beta_{\lambda f u l l}$, $\beta_{\lambda \text { part }}, \beta_{\lambda n o}$ は統計的に有意であれば，サンプ ル・セレクション・バイアスが存在することを意 味する.

最後に所得格差に関する要因分解式について説 明する．2つのグループ間（例えば，都市正規と 都市非正規，都市正規と出稼ぎ正規など）の所得 関数を（9）式で示す ${ }^{11)}$.

$\ln$ income $_{a}=\beta_{a} X_{a}+\varepsilon_{a}$

$\ln$ income $_{b}=\beta_{b} X_{b}+\varepsilon_{b}$

(9）式で下付きの添字 $a$ および $b$ は 2 つのグル 一プを示す. $\ln$ income $_{a}$ および $\ln$ income $_{b}$ は $a$ と $b$ の時間あたり所得の対数, $X_{a}$ および $X_{b}$ は所 得に影響を与える各要因, $\beta_{a}$ および $\beta_{b}$ は所得 関数で求められる各要因の推定係数, $\varepsilon_{a}$ および $\varepsilon_{b}$ は $a$ グループと $b$ グループの所得関数の誤差 項をそれぞれ示す。

Oaxaca（1973），Blinder（1973）は，労働生産性 の差異に起因する格差 (differentials)，および労働 生産性が同じでも差別的取扱いに起因する格差 (discriminations) によって, 所得格差 $\left(\ln \overline{\text { income }}_{a}\right.$ $-\ln \overline{\text { income }}_{b}$ ） が生じると指摘している. 前者を 平均值の違いに基づく格差(以下では,「属性格差」 と呼ぶ), 後者を推定係数に基づく格差(以下では, 「非属性格差」と呼ぶ）と定義している. (10)-1 式 （ $a$ 基準）と（10）-2 式（ $b$ 基準）を用いると， 属性格差と非属性格差の所得格差への寄与度を計 測することができる。

\section{$\ln \overline{\text { income }}_{a}-\ln \overline{\text { income }}_{b}$}

$$
=\frac{\left(\bar{X}_{a}-\bar{X}_{b}\right) \beta_{a}}{\text { 属性格差 }}+\frac{\bar{X}_{b}\left(\beta_{a}-\beta_{b}\right)}{\text { 非属性格差 }} \quad(10)-1
$$

または,

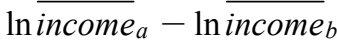

$=\frac{\left(\bar{X}_{b}-\bar{X}_{a}\right) \beta_{b}}{\text { 属性格差 }}+\frac{\bar{X}_{a}\left(\beta_{b}-\beta_{a}\right)}{\text { 非属性格差 }}$

(10)- 1 式，(10)-2 式において,「 $\overline{\text { income }}_{a}$ $\ln \overline{\text { income }}_{b} 」$ は $a$ グループと $b$ グループの平均所 得の対数值の差, $\bar{X}_{a}$ および $\bar{X}_{b}$ は各要因の平均 值, $\beta_{a}$ および $\beta_{b}$ は所得関数で求められる各要因
の推定係数を示す.

（10）- 1 式，(10）- 2 式の要因分解式に対して,

Reimers (1983), Cotton (1988), Neumark (1988) および Oaxaca and Ransom（1994）は，基準の取り 方（ $a$ 基準か $b$ 基準か）によって推定結果が異な る問題, つまりインデックス問題が存在すること を指摘している．本稿ではインデックス問題に対 応するため，Oaxaca and Ransom（1994）モデルを 用いている. Oaxaca and Ransom（1994）で用いら れた「非差別的賃金構造の係数」(「 $\left.\beta^{*} 」\right)$ を(10) -1 式，(10）- 2 式に代入すれば，(10)- 1 式，(10) -2 式は (11) 式のように一本化することができる. 本稿の分析では，(11）式を用いて各グループ間の 所得格差に関する要因分解の分析を行う.

\section{$\ln \overline{\text { income }}_{a}-\ln \overline{\text { income }}_{b}$}

$=\frac{\left(\bar{X}_{a}-\bar{X}_{b}\right) \beta^{*}}{\text { 属性格差 }}+\frac{\bar{X}_{a}\left(\beta_{a}-\beta^{*}\right)+\bar{X}_{b}\left(\beta^{*}-\beta_{b}\right)}{\text { 非属性格差 }}$

（11）式の意味について説明する.（11）式の右 辺において，第 1 項は属性格差，第 2 項は $a$ グル 一プの損失，第 3 項は $b$ グループの利得をそれぞ れ示寸. 第 2 項と第 3 項の合計值は非属性格差で ある。ここでの非属性格差は，主に労働生産性の 差異以外の要因, つまり各要因に対する評価の差 異に起因寸る部分（例えば，差別的取扱い，異な る賃金決定制度など）が所得格差に与える影響を 示す ${ }^{12)}$. 非属性格差が大きくなるほど, 労働生産 性以外の要因の影響が大きくなり, 労働市場が分 断される可能性が高くなることを意味する．労働 市場の分断化の問題を検討する際に，非属性格差 の計測結果に注目することが必要である.

また, 要因分解の分析では所得関数で用いた説 明変数が異なると, 要因分解の結果が異なる可能 性が存在する. 本稿では分析結果の頑健性をチェ ックするため, 教育年数および経験年数を用いた 要因分解を「分解 $1 」$ (人的資本モデル), 教育年 数, 経験年数および党員を用いた要因分解を「分 解 $2 」$ (「人的資本十政治資本」モデル), 人的資本, 政治資本およびそれ以外の各要因を用いた要因分

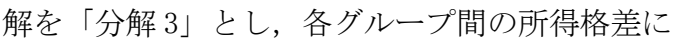
関する 3 種類の要因分解の分析を行う. 


\section{2 用いたデータおよび変数設定の説明}

本稿では2002年中国都市出稼ぎ労働者所得調査 （MCHIP 2002）および2002年中国都市戸籍住民所 得調査（UCHIP 2002）の個票データを利用する. 2 種類の調查は, 2003年に中国社会科学院経済研 究所と国家統計局が実施した全国の代表的な地域 における労働者を調查対象とする家計所得調査で ある.前者は主に都市戸籍住民を対象とした調査, 後者は主に出稼ぎ労働者を対象とした調查である. 2 種類の調查では質問項目が部分的に同じである ため, 都市戸籍住民と出稼ぎ労働者の所得格差に 関する実証分析に利用できる. 有効回答の標本数 は MCHIP 2002が5, 327人，UCHIP 2002が20, 632 人となっている.

次に用いた変数の定義について説明する. 被説 明変数については，(1) 就業形態の確率に関する 多項ロジット分析では, カテゴリー変数 (正規 $=1$, 非正規 $=2$, 非就業 $=3 ）$ を被説明変数として用い る. 正規と非正規の分類基準については，中国の 特有な状況を考慮し， ILO（1972）を参照にした うえで, MCHIP 2002および UCHIP 2002調査票の 質問項目に基づいて, 勤め先の企業所有制形態, 労働契約状況, 職種の 3 つの基準に合わせて分類 している，具体的にいえば，（中央・省）国有独資 企業，（地方）国有独資企業，都市集団企業，国家 持ち株会社に勤める労働者, 終身雇用 (国家幹部,

公務員を含む）と長期・短期的労働契約をした労 働者, 国家機関・党政機関・社会団体の労働者を 正規就業者グループとする.他方, 都市民営企業, 都市個人企業，中外合資企業，外資企業，その他 の株式会社, 農村民営企業, 農村個人企業に勤め る労働者，労働契約をしていない労働者を非正規 就業者グループとする. また離職者, 退職者, レ イオフ者, 早期退職者, 失業者, 家事を専業とす る者, 他の非就業者をすべて非就業者グループと する.（2）所得関数では，時間あたり所得対数を 被説明変数として用いている. 時間あたり所得は, 毎月の労働所得を対応する月労働時間で割ったも のである。

説明変数については, 本稿では, 先行研究で用 いられる説明変数を参照した上で, 主に人的資本, 政治資本，他の要因に分けてそれぞれの変数を設 定した ${ }^{13)}$.
（1）Becker（1964），Mincer（1974）の人的資 本理論によれば，人的資本が所得に影響を与える と考えられる. そのため, 本稿でも先行研究で通 常用いられる教育年数 ${ }^{14)}$, 経験年数, 経験年数の 2 乗 ${ }^{15)}$ を基本的な人的資本の代理指標として設定 している ${ }^{16)}$.

（2）中国における社会政治制度の主な特徴は, 共産党という政治組織が存在し，社会経済のあら ゆる面で強大な影響力を有していることである. Gustafsson and Li (2000), 佐藤 (2003), 㛜 (2008), 馬 (2008a, 2009b, 2009c) は, 所得関数で党員ダミ 一を用いており, 所得は党員が非党員より高いこ と（party premium）を指摘している. 本稿では党員 ダミーを政治資本の代理指標として設定している.

(3) Neumark (2004), Gustafsson and Li (2000) は, 健康ダミーを用いており, アメリカと中国に おいて，いずれも所得は健康者が非健康者より高 いことを示している. 本稿では健康状況が所得に 与える影響をコントロールするため, 健康ダミー を説明変数として採用している.

（4）戸田・馬（2005）は，日本において転職経 験が賃金所得に影響を与えることを示しており， また Knight・李 (2004), 馬 (2008b) は失業経験, 転職経験が中国労働者の所得に影響を与えること を指摘している。本稿では, 転職経験の影響を統 御寸るため, 転職ありダミー（転職経験があった 場合 $=1$ ，転職経験がなかった場合＝0）を設定し ている.

（5） Neumark（2004）は，アメリカで男性賃金 は既婚者が独身者より高く, つまり結婚の賃金プ レミアム (marry premium) が存在することを示し ている. 本稿でも婚姻状況の所得への影響を考慮 するため，既婚ダミーを設定している.

(6) Oaxaca (1973), Blinder (1973), Reimers (1983), Cotton (1988), Neumark (1988), Oaxaca and Ransom（1994）は，欧米で性別によって賃金 所得が異なることを明らかにしている。また， Gustafsson and Li (2000) と馬 (2009c) は, 中国 都市労働者における男女間所得格差が存在するこ とを指摘している，そこで本稿においても性別の 影響を統御するため, 男性ダミーを設定している.

（7）Roberts (2001), 宋・Appleton (2006) は, 中国では出稼ぎ労働者は主に製造業, サービス業 


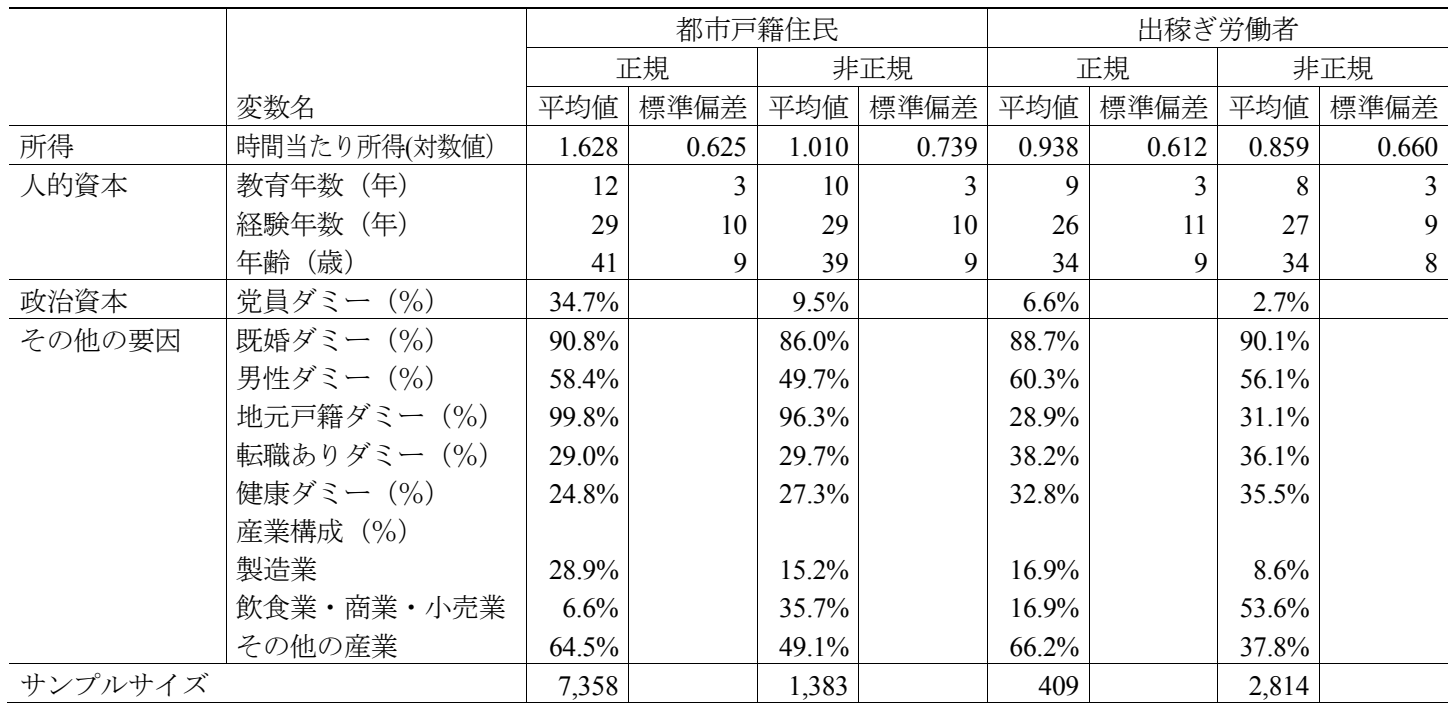

出所 : 表 1 と同じ.

などの産業に集中すると述べている．産業構造の 差異が所得に影響を与えると考えられるため, 3 つの産業ダミー（製造業ダミー，飲食業・商業・ 小売業ダミー，その他の産業ダミー）を設定して いる.

（8）蔡・白（2006）は，中国では地方政府が地 元戸籍を持つ労働者の就業を守るため, 非地元戸 籍を持つ外来労働者（非地元労働者）に対して産 業, 職種に進入する制限を設けている問題を指摘 している．また，厳（2008）は上海において地元 労働者と非地元労働者間の賃金構造が異なること を示している. 中国企業の労働雇用において地元 労働者と非地元労働者間の格差が存在し，つまり 非地元労働者に対する差別的取扱いの問題が存在 すると考えられる，そのため, 就業形態に関する 分析で地元戸籍ダミーを用いている.

(9) Knight, Song and Jia（1999），Gustafsson and Li (2000), 佐藤 (2003), 厳 (2008), 馬 (2009b; 2009c）では，企業所有制，職種ダミーが用いられ ている. 企業所有制, 職種が中国労働者の所得に 影響を与えると考えられるが，本稿では正規，非 正規を分類する際に, これらの情報を用いている. そのため, 企業所有制, 職種が説明変数として用 いられていない17).

最後にサンプルの選定について説明する．本稿 では都市戸籍住民と出稼ぎ労働者のサンプルを用
いた．国有部門における定年制度の影響を考慮し た上で，分析対象の年齢を $16 \sim 60$ 歳に限定し，ま た欠損值および異常值を除外した. 分析で用いた サンプル数は都市正規者が 7,358 人, 都市非正規者 が 1,383 人，出稼ぎ正規者が 408 人，出稼ぎ非正規 者が2, 814 人である. 記述統計量および各要因の構 成比を表 2 で示している.

\section{4 計量分析の結果}

\section{1 就業形態の選択に関する分析の結果}

就業形態の選択に関する多項ロジット分析およ び多項プロビット分析の結果を表 3 で示している. 二つのモデルを用いた推定結果では, 各変数の推 定係数が若干異なるものの, それらの推定結果の 傾向がほぼ同じであり, 就業形態の選択に関する 推定結果に頑健性があることが示された. 以下で は主に人的資本と政治資本に関する分析結果を検 討する.

まず，人的資本の影響については，（1）教育水 準が高くなるほど, 都市戸籍住民において, 正規 者および非正規者になる可能性が高くなる.一方， 教育水準は出稼ぎ労働者の就業形態の選択には有 意な影響を与えていない。（2）年齢は都市正規, 都市非正規, 出稼ぎ非正規になる可能性に有意な 影響を与えている一方, 出稼ぎ正規になる確率に は有意な影響を与えていない。これらの分析結果 
表3 出稼ぎ労働者と都市戸籍住民の就業形態の選択に関する分析結果

\begin{tabular}{|c|c|c|c|c|c|c|c|c|}
\hline & \multicolumn{4}{|c|}{ 多項ロジット分析モデル } & \multicolumn{4}{|c|}{ 多項プロビット分析モデル } \\
\hline & \multicolumn{2}{|c|}{ 都市戸籍住民 } & \multicolumn{2}{|c|}{ 出稼ぎ労働者 } & \multicolumn{2}{|c|}{ 都市戸籍住民 } & \multicolumn{2}{|c|}{ 出稼ぎ労働者 } \\
\hline & 正規 & 非正規 & 正規 & 非正規 & 正規 & 非正規 & 正規 & 非正規 \\
\hline \multirow[t]{2}{*}{ 教育年数 } & $0.240^{* * *}$ & $0.034 * * *$ & 0.050 & -0.054 & $0.110 * * *$ & $-0.057 * * *$ & 0.054 & -0.048 \\
\hline & $(24.67)$ & $(2.81)$ & $(0.90)$ & $(-1.03)$ & $(25.93)$ & $(-11.24)$ & $(0.92)$ & $(-0.63)$ \\
\hline \multirow[t]{2}{*}{ 年齢 } & $0.598 * * *$ & $0.498 * * *$ & 0.097 & $0.311 * * *$ & $0.316^{* * *}$ & $0.164 * * *$ & -0.106 & $0.122 * * *$ \\
\hline & $(24.43)$ & $(14.85)$ & $(0.88)$ & $(2.97)$ & $(31.48)$ & $(12.76)$ & $(-1.40)$ & $(5.38)$ \\
\hline \multirow[t]{2}{*}{ 年齢の 2 乗 } & $-0.008 * * *$ & $-0.007 * * *$ & -0.001 & $-0.004 * * *$ & $-0.004 * * *$ & $-0.002 * * *$ & 0.001 & $-0.002 * * *$ \\
\hline & $(-27.23)$ & $(-17.07)$ & $(-0.68)$ & $(-2.80)$ & $(-32.59)$ & $(-13.84)$ & $(0.64)$ & $(-5.65)$ \\
\hline \multirow[t]{2}{*}{ 転職あり } & $5.316 * * *$ & $5.224 * * *$ & -0.387 & -0.407 & $0.576 * * *$ & $0.230^{* * *}$ & 0.013 & -0.020 \\
\hline & (12.92) & (12.62) & $(-1.37)$ & $(-1.54)$ & (19.30) & $(6.66)$ & $(0.22)$ & $(-0.37)$ \\
\hline \multirow[t]{2}{*}{ 健康 } & $0.171^{* * *}$ & $0.181^{* * *}$ & 0.320 & 0.423 & $0.155^{* * *}$ & $0.081 * *$ & -0.168 & 0.233 \\
\hline & (2.69) & $(2.22)$ & $(1.02)$ & $(1.42)$ & $(6.22)$ & $(2.50)$ & $(-1.78)$ & (1.66) \\
\hline \multirow[t]{2}{*}{ 党員 } & $0.832 * * *$ & $-0.323 * * *$ & 0.353 & -0.341 & $0.507 * * *$ & $-0.471^{* * *}$ & 0.371 & -0.407 \\
\hline & $(12.28)$ & $(-2.91)$ & $(0.46)$ & $(-0.45)$ & (16.88) & $(-10.55)$ & (1.74) & $(-1.13)$ \\
\hline \multirow[t]{2}{*}{ 既婚 } & $0.294^{* * *}$ & $0.146^{* * *}$ & -0.066 & -0.466 & $0.226 * * *$ & -0.028 & 0.206 & -0.203 \\
\hline & $(2.65)$ & $(1.04)$ & $(-0.13)$ & $(-0.959)$ & $(4.74)$ & $(-0.46)$ & (1.78) & $(-1.87)$ \\
\hline \multirow[t]{2}{*}{ 男性 } & $1.346^{* * *}$ & $1.151 * * *$ & $0.855^{* * *}$ & $0.808 * * *$ & $0.459 * * *$ & $0.088^{* * *}$ & $0.020 * * *$ & $0.018^{* * *}$ \\
\hline & $(24.50)$ & (15.93) & $(2.90)$ & $(2.90)$ & (19.57) & $(2.96)$ & (3.35) & $(4.32)$ \\
\hline \multirow[t]{2}{*}{ 地元戸籍 } & $1.479 * * *$ & $-1.007 * * *$ & $-0.560 * *$ & -0.422 & $1.241 * * *$ & $-0.822 * * *$ & $-0.075 * *$ & 0.036 \\
\hline & $(4.27)$ & $(-3.91)$ & $(-1.96)$ & $(-1.58)$ & $(7.99)$ & $(-7.35)$ & $(-2.62)$ & $(0.63)$ \\
\hline \multirow[t]{2}{*}{ 定数項 } & $-14.992 * * *$ & $-8.935 * * *$ & -0.680 & -1.286 & $-9.076 * * *$ & $-2.713^{* * *}$ & -0.191 & $-0.718 *$ \\
\hline & $(-25.54)$ & $(-13.61)$ & $(-0.37)$ & $(-0.74)$ & $(-36.90)$ & $(-11.11)$ & $(-0.45)$ & $(-1.82)$ \\
\hline \multirow[t]{2}{*}{ atrho21 } & & & & & $2.816 * * *$ & & 4.563 & \\
\hline & & & & & 6.14 & & 0.12 & \\
\hline \multirow[t]{2}{*}{ atrho31 } & & & & & $-2.917 * * *$ & & $-0.731 * * *$ & \\
\hline & & & & & -21.12 & & -4.59 & \\
\hline \multirow[t]{2}{*}{ atrho23 } & & & & & $-2.532 * * *$ & & $-0.577 * * *$ & \\
\hline & & & & & -7.35 & & -5.77 & \\
\hline 標本数 & 12487 & & 3322 & & 12487 & & 3322 & \\
\hline 対数尤度 & -8429.993 & & -1498.800 & & -8405.600 & & -1496.476 & \\
\hline LR 值 & 6008.290 & & 96.810 & & 6057.080 & & 101.460 & \\
\hline 尤度比検定 & 0.000 & & 0.000 & & 0.000 & & 0.000 & \\
\hline
\end{tabular}

注 1）*,**,***はそれぞれ有意水準10\%，5\%，1\%を示す.

2）レファレンス組は非就業者である.

3）（）内の数值は $\mathrm{z}$ 值である.

出所 : 表 1 と同じ.

により，人的資本が就業形態の選択に与える影響 は都市労働者に関して出稼ぎ労働者より大きい傾 向にあることが示された.

次に政治資本の影響については，(1）党員ダミ 一が都市戸籍住民の就業形態に有意な影響を与え ている一方, 出稼ぎ労働者の就業形態には有意な 影響を与えていない．政治資本が労働者の就業に 与える影響は, 都市労働者に関して出稼ぎ労働者 より大きいことが示された（2）都市戸籍住民の グループにおいて, 党員の場合, 正規就業者にな る可能性が高くなり，党員の身分は都市正規者に なる可能性を高める効果を持つことが確認された. 一方，党員の場合，都市非正規者になる可能性は 都市失業者になる可能性より低い結果も得られた。
政治資本は労働者が正規部門を選択寸る可能性に 与える影響は最も大きいことが示された。これら の分析結果が得られた理由は，非正規部門で市場 メカニズムの影響が大きい一方，正規部門で市場 メカニズム以外の制度的要因の影響も大きいこと にあると考えられる。

\section{2 所得関数の推定結果}

OLS による所得関数に関する推定結果を表 4 で 示しており, 二段階の推定法による所得関数の推 定結果を表 5 でまとめている ${ }^{18)}$ 。まず，OLS の推 定結果にサンプル・セレクション・バイアスが存 在するかどうかについて検討する.表 5 によれば, 都市正規者の推定結果で, 逆ミルズ比の有意水準 
表4 所得関数の推定結果 （OLS）

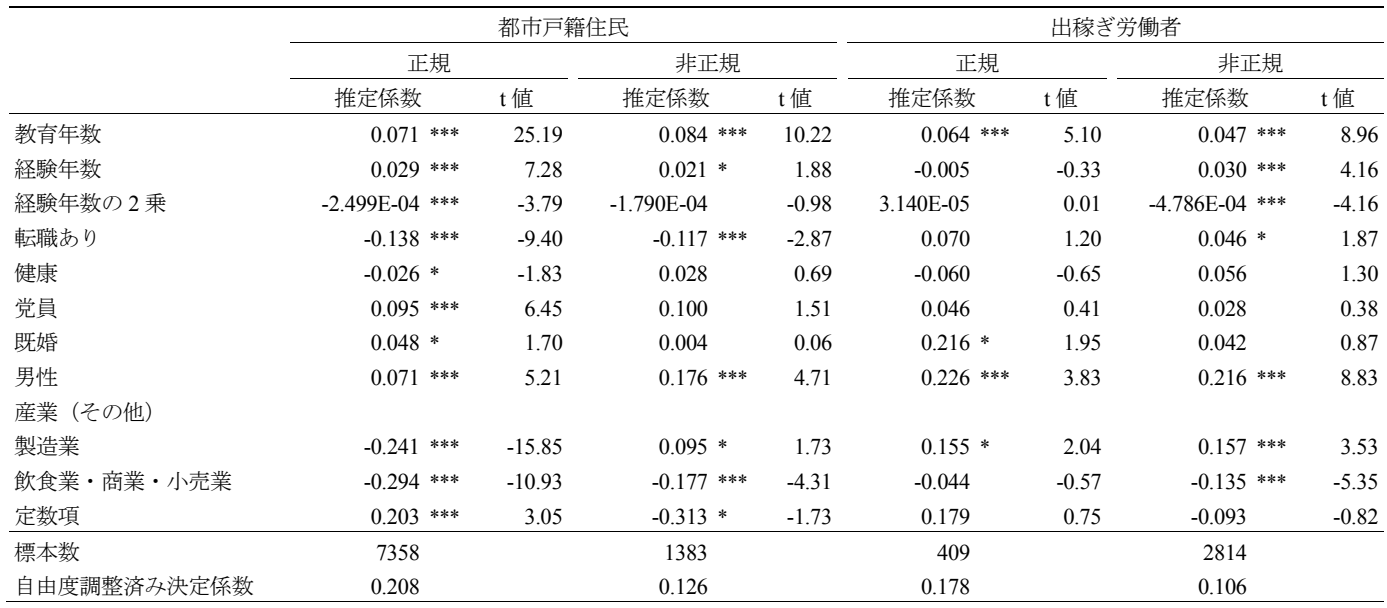

注 1）*,**,***はそれぞれ有意水準10\%，5\%，1\%を示す.

2）OLSによる計測.

出所 : 表 1 と同じ.

表5 所得関数の推定結果 （二段階の推定法）

\begin{tabular}{|c|c|c|c|c|c|c|c|c|c|c|c|c|}
\hline & \multicolumn{6}{|c|}{ 都市戸籍住民 } & \multicolumn{6}{|c|}{ 出稼ぎ労働者 } \\
\hline & \multicolumn{3}{|c|}{ 正規 } & \multicolumn{3}{|c|}{ 非正規 } & \multicolumn{3}{|c|}{ 正規 } & \multicolumn{3}{|c|}{ 非正規 } \\
\hline & 推定係数 & & $\mathrm{z}$ 值 & 推定係数 & & $\mathrm{z}$ 值 & 推定係数 & & $\mathrm{z}$ 值 & 推定係数 & & $\mathrm{z}$ 值 \\
\hline 教育年数 & 0.056 & $* * *$ & 11.19 & 0.078 & $* * *$ & 6.63 & 0.063 & $* * *$ & 2.96 & 0.055 & $* * *$ & 5.53 \\
\hline 経験年数 & 0.025 & $* * *$ & 5.31 & 0.022 & $*$ & 1.63 & 0.001 & & 0.05 & 0.001 & & 0.05 \\
\hline 経験年数の 2 乗 & $-2.076 \mathrm{E}-04$ & $* *$ & -2.49 & $-1.903 \mathrm{E}-04$ & & -0.84 & $-5.810 \mathrm{E}-05$ & & -0.14 & $-3.880 \mathrm{E}-05$ & & -0.18 \\
\hline 転職あり & -0.153 & $* * *$ & -5.88 & -0.212 & $* *$ & -2.42 & 0.066 & & 1.06 & 0.097 & $* * *$ & 3.51 \\
\hline 健康 & 0.024 & $*$ & 1.72 & 0.029 & & 0.70 & -0.059 & & -0.64 & 0.038 & & 0.88 \\
\hline 党員 & 0.031 & $* * *$ & 3.32 & 0.054 & & 0.72 & -0.004 & & -0.02 & 0.122 & & 1.14 \\
\hline 既婚 & 0.029 & & 0.99 & -0.016 & & -0.20 & 0.214 & $*$ & 1.67 & 0.103 & $*$ & 1.80 \\
\hline 男性 & 0.054 & $* * *$ & 3.04 & 0.143 & $* * *$ & 2.79 & 0.243 & $* * *$ & 2.82 & 0.128 & $* * *$ & 3.81 \\
\hline \multicolumn{13}{|l|}{ 産業（その他） } \\
\hline 製造業 & -0.240 & $* * *$ & -15.77 & 0.090 & $*$ & 1.64 & 0.149 & $*$ & 1.94 & 0.160 & $* * *$ & 3.60 \\
\hline 飲食業・商業・小売業 & -0.292 & $* * *$ & -10.84 & -0.179 & $* * *$ & -4.35 & -0.044 & & -0.56 & -0.130 & $* * *$ & -5.16 \\
\hline 定数項 & -0.880 & & -0.75 & -5.689 & $* *$ & -1.98 & -28.500 & & -0.89 & -14.449 & & -0.93 \\
\hline \multicolumn{13}{|l|}{ 逆ミルズ比 } \\
\hline 正規就業 & 0.201 & & 0.28 & 3.081 & $*$ & 1.88 & 14.971 & & 0.88 & 4.272 & & 0.51 \\
\hline 非正規就業 & 1.349 & $* *$ & 2.11 & 2.834 & $*$ & 1.80 & 21.265 & & 0.96 & 4.582 & & 0.42 \\
\hline 非就業 & -0.452 & & -0.67 & -3.153 & $*$ & -1.88 & -13.411 & & -0.82 & -12.779 & $*$ & -1.69 \\
\hline 標本数 & 7358 & & & 1383 & & & 409 & & & 2814 & & \\
\hline 自由度調整済双決定係数 & 0.209 & & & 0.126 & & & 0.174 & & & 0.111 & & \\
\hline
\end{tabular}

注 1）*,**,***はそれぞれ有意水準10\%，5％，1\%を示す.

2）二段階の推定法による計測.

3）逆ミルズ比は多項プロビットモデルの推定結果を用いて算出.

出所 : 表 1 と同じ.

が $5 \%$ となっている．また都市非正規者，出稼ぎ 非正規者に関する推定結果では，逆ミルズ比の有 意水準が10\%となっている.これらの分析結果に より, OLS よる所得関数の推定結果に標本の非ラ ンダム性の問題が存在するが，都市正規者以外の グループにおいてサンプル・セレクション・バイ
アスの問題が顕著ではないことが示された．OLS と二段階の推定法による推定結果の傾向はほぼ同 じであるが, 以下では二段階の推定法による所得 関数の推定結果（表 5) について説明する.

第 1 に，人的資本の影響をみる.（1）学歴の影 響については, 教育の収益率は, 都市正規が $5.6 \%$, 
都市非正規が $7.8 \%$ ，出稼ぎ正規が $6.3 \%$ ，出稼ぎ 非正規が5. 5\%となっている.各グループにおいて， いずれも教育水準が高くなるほど所得が高くなる 傾向にある．教育の効果に関する本稿の分析結果 は，李・丁（2004）, Margaret and Ngan（2004）に 類似し，人的資本理論と整合的である。また教育 水準が所得に与える影響は，都市労働者の場合の 方が出稼ぎ労働者より大きいことが示された. (2) 経験年数の影響については, 経験年数の上昇とと もに都市正規者の所得が高くなる。一方，経験年 数は出稼ぎ労働者の所得には有意な影響を与えて いない.これらの分析結果から, 正規部門での年功 賃金制度は都市正規者のみを優遇対象としている ことがうかがえる。

第 2 に，政治資本については，党員ダミーが都 市正規者の所得に有意な影響を与えている，具体 的に，非党員の場合に比へ，党員である場合，都 市正規者の所得の対数值がそれぞれ $3.1 \%$ 高くな る. 都市正規者の所得における党員プレミアムに ついては，以下のことが考えられる。（1）都市正 規者の大多数が国有企業で働いており，国有企業 では管理職などの職位・職階に昇進する可能性は 党員グループが非党員グループより高い，上位の 職位・職階への昇進における党員と非党員間の格 差が存在するため, 他の条件が一定である場合, 党員の平均所得の水準が非党員より高くなると考 えられる.（2）国有企業では，人事評価を行う際 に，上司からの評価が重要である，管理職で党員 の割合が高く，党員間の人間関係（party membership）が存在すれば，非党員の労働者に比 べ，上司の評価は党員である労働者のほうが高く なる. 人事評価における党員と非党員間の格差が 存在するため, 所得の党員プレミアムが現れると 考えられる.

第 3 に，他の要因について検討する。（1）都市 正規者，都市非正規者のいずれにおいて，転職者 の所得は非転職者に比べて低くなる，一方，出稼 ぎ非正規者において，非転職者に比心゙，転職者の 場合，所得が高くなる．転職が所得に与える影響 に関して，都市戸籍住民と出稼ぎ労働者間で差異 の存在することがわかった。（2）男女間所得格差 については，他の要因が一定であれば，女性に比 べ，男性の所得は，それぞれ5.4\%（都市正規）,
$14.3 \%$ (都市非正規), $24.3 \%$ (出稼ぎ正規), $12.8 \%$ （出稼ぎ非正規）高くなる. 男女間所得格差は, 非 正規者について正規者より大きくなり，とくに都 市正規者の場合，格差が最も小さいことが示され た.（3）産業の影響については, 都市戸籍住民, 出稼ぎ労働者いずれにおいても産業間の所得格差 が存在しており，他の条件が一定であれば，飲食 業・商業・小売業における所得が製造業より低く なる傾向にある.

\section{3 所得格差に関する要因分解の結果}

各グループ間の所得格差に関する要因分解の結 果を表 6 -（1）, 表 6 - (2), 表 7-（1）, 表 7-（2） で示している. 分解 1 , 分解 2 , 分解 3 の分析結果 が若干異なるが，傾向はほぼ同じであるため，以 下では, 主に分解 3 の結果について説明する.

第 1 に，各グループ間で所得格差の大きさが異 なっている，分解 3 によれば，所得格差は，都市 正規と出稼ぎ正規間 $(0.6912)$ および都市正規と 出稼ぎ非正規間（0.6182）が，都市非正規と出稼 ぎ非正規間（0.1485）および出稼ぎ正規と出稼ぎ 非正規間（0.0754）より大きい。都市正規者と出 稼ぎ労働者間の所得格差が大きいことが目立つ.

第 2 に, 部門内格差の要因を検討寸る.（1）都 市正規と出稼ぎ正規間の所得格差について, 所得 格差への寄与度は属性格差が55.0\%で非属性格差 （45\%）より大きい。属性格差において，寄与度は 教育年数が $37.5 \%$ で最も大きく, 次いで経験年数 が $10.0 \%$, 党員が $4.1 \%$ となっている.一方, 非属 性格差において, 経験年数が $91.4 \%$ で最も大きく, 次いで教育年数が $2.4 \%$, 党員が $0.2 \%$ となってい る.（2）都市非正規と出稼ぎ非正規間の所得格差 については, 所得格差への寄与度は属性格差が 104.6\%, 非属性格差が-4.6\%である. 属性格差 が都市非正規と出稼ぎ非正規間の所得格差に大き な影響を与える一方, 非属性格差がその所得格差 の縮小に寄与することが示された。 また属性格差 において, 寄与度は教育年数が $88.0 \%$ で最も大き く, 次いで産業が $23.7 \%$, 党員が $4.3 \%$, 経験年数 が2. $8 \%$ となっており, 非属性格差において教育年 数が $315.1 \%$ で最も大きく, 次いで経験年数が $27.9 \%$, 産業が7. $3 \%$, 党員が $5.9 \%$ となっている. 部門内格差の要因分解の結果により, 以下のこと 
表6－（1） 部門内格差に関する要因分解 （都市正規と出稼ぎ正規）

寄与度：\%

\begin{tabular}{|c|c|c|c|c|}
\hline \multirow{2}{*}{$\begin{array}{l}\text { 正規部門 } \\
\text { 都市戸籍住民と } \\
\text { 出稼ぎ労働者 }\end{array}$} & \multirow{2}{*}{$\begin{array}{l}\text { 属性格差 } \\
\text { (1) }\end{array}$} & \multicolumn{3}{|c|}{ 非属性格差 } \\
\hline & & \begin{tabular}{|l|} 
都市者の利得 \\
(2) \\
\end{tabular} & \begin{tabular}{|l|} 
農民工の損失 \\
(3) \\
\end{tabular} & $\begin{array}{r}\text { 合計 } \\
\text { (2) }+ \text { (3) }\end{array}$ \\
\hline \multicolumn{5}{|c|}{\begin{tabular}{l|l} 
分解 1 & \\
\end{tabular}} \\
\hline 実際値 $=0.699$ & 0.407 & 0.016 & 0.277 & 0.292 \\
\hline 合計 $=100 \%$ & $58.2 \%$ & $2.2 \%$ & $39.6 \%$ & $41.8 \%$ \\
\hline 各要因の寄与度 & & & & \\
\hline 教育年数 & $45.6 \%$ & $-14.2 \%$ & $23.7 \%$ & $9.5 \%$ \\
\hline 経験年数 & $12.5 \%$ & $-8.1 \%$ & $55.1 \%$ & $47.0 \%$ \\
\hline 定数項 & $0.0 \%$ & $24.5 \%$ & $-39.2 \%$ & $-14.6 \%$ \\
\hline \multicolumn{5}{|l|}{ 分解 2} \\
\hline 実際値 $=0.697$ & 0.408 & 0.015 & 0.274 & 0.289 \\
\hline 合計 $=100 \%$ & $58.6 \%$ & $2.2 \%$ & $39.3 \%$ & $41.4 \%$ \\
\hline 各要因の寄与度 & & & & \\
\hline 教育年数 & $42.1 \%$ & $-13.9 \%$ & $16.1 \%$ & $2.2 \%$ \\
\hline 経験年数 & $11.3 \%$ & $-7.9 \%$ & $48.8 \%$ & $40.9 \%$ \\
\hline 党員 & $5.2 \%$ & $-0.2 \%$ & $0.5 \%$ & $0.3 \%$ \\
\hline 定数項 & $0.0 \%$ & $24.3 \%$ & $-26.2 \%$ & $-2.0 \%$ \\
\hline \multicolumn{5}{|l|}{ 分解 3} \\
\hline 実際値 $=0.691$ & 0.380 & 0.016 & 0.295 & 0.311 \\
\hline 合計 $=100 \%$ & $55.0 \%$ & $2.3 \%$ & $42.7 \%$ & $45.0 \%$ \\
\hline 各要因の寄与度 & & & & \\
\hline 教育年数 & $37.5 \%$ & $-18.5 \%$ & $20.8 \%$ & $2.4 \%$ \\
\hline 経験年数 & $10.0 \%$ & $-8.8 \%$ & $100.2 \%$ & $91.4 \%$ \\
\hline 党員 & $4.1 \%$ & $-0.4 \%$ & $0.6 \%$ & $0.2 \%$ \\
\hline 男性 & $-0.2 \%$ & $-0.3 \%$ & $-13.7 \%$ & $-14.0 \%$ \\
\hline 既婚 & $0.1 \%$ & $2.8 \%$ & $-23.6 \%$ & $-20.8 \%$ \\
\hline 健康 & $1.3 \%$ & $1.5 \%$ & $2.5 \%$ & $4.0 \%$ \\
\hline 転職あり & $1.7 \%$ & $-0.1 \%$ & $-11.5 \%$ & $-11.6 \%$ \\
\hline 産業 & $0.5 \%$ & $-1.8 \%$ & $-14.8 \%$ & $-16.6 \%$ \\
\hline 定数項 & $0.0 \%$ & $27.9 \%$ & $-17.9 \%$ & $10.0 \%$ \\
\hline
\end{tabular}

注) Oaxaca and Ransom(1994) モデルを用いた計測. 出所 : 表 1 と同じ.

が示された。（1）部門内格差の主な要因について は, 教育水準, 経験年数, 産業分布, 党員割合の 差異 (属性格差)，および人的資本，政治資本に対 する評価の格差（非属性格差）は，出稼ぎ労働者 と都市戸籍住民間の所得格差に大きな影響を与え ることが示された。また所得格差に与える影響は 人的資本が政治資本より大きいことがわかった。

（2）非属性格差が所得格差に寄与し，同一部門で は，労働者が持つ戸籍（農村戸籍と都市戸籍）に より人的資本と政治資本に対する評価が異なるこ とが明らかになっている。同一部門（非正規部門 あるいは正規部門）の労働市場は労働者が持つ戸 籍によって分断されることが示された. 非正規部 門における都市戸籍住民と出稼ぎ労働者の所得格 差に関する要因分解の結果は Meng (2001), 馬 (2008a)に一致している.また本稿の分析により,
表6－（2） 部門内格差に関する要因分解 （都市非正規と出稼ぎ非正規）

寄与度 : \%

\begin{tabular}{|c|c|c|c|c|}
\hline \multirow{2}{*}{$\begin{array}{l}\text { 非正規部門 } \\
\text { 都市戸籍住民と } \\
\text { 出稼ぎ労働者 }\end{array}$} & \multirow{2}{*}{$\begin{array}{l}\text { 属性格差 } \\
\text { (1) }\end{array}$} & \multicolumn{3}{|c|}{ 非属性格差 } \\
\hline & & $\begin{array}{l}\text { 都市者の利得 } \\
\text { (2) }\end{array}$ & $\begin{array}{l}\text { 農民工の損失 } \\
\text { (3) } \\
\end{array}$ & $\begin{array}{r}\text { 合計 } \\
\text { (2) }+ \text { (3) }\end{array}$ \\
\hline 分解 1 & & & & \\
\hline 実際伹 $=0.148$ & 0.164 & -0.011 & -0.005 & -0.016 \\
\hline 合計 $=100 \%$ & $110.8 \%$ & $-7.2 \%$ & $-3.5 \%$ & $-10.8 \%$ \\
\hline 各要因の寄与度 & & & & \\
\hline 教育年数 & $104.0 \%$ & $156.1 \%$ & $48.7 \%$ & $204.8 \%$ \\
\hline 経験年数 & $6.8 \%$ & $23.7 \%$ & $10.5 \%$ & $34.2 \%$ \\
\hline 定数項 & $0.0 \%$ & $-187.1 \%$ & $-62.7 \%$ & $-249.7 \%$ \\
\hline 分解 2 & & & & \\
\hline 実際值 $=0.148$ & 0.165 & -0.011 & -0.006 & $-1.7 \%$ \\
\hline 合計 $=100 \%$ & $111.8 \%$ & $-7.7 \%$ & $-4.1 \%$ & $-11.8 \%$ \\
\hline 各要因の寄与度 & & & & \\
\hline 教育年数 & $100.7 \%$ & $146.9 \%$ & $41.4 \%$ & $188.3 \%$ \\
\hline 経験年数 & $5.6 \%$ & $12.6 \%$ & $2.0 \%$ & $14.7 \%$ \\
\hline 党員 & $5.4 \%$ & $0.1 \%$ & $0.7 \%$ & $0.7 \%$ \\
\hline 定数項 & $0.0 \%$ & $-167.4 \%$ & $-48.2 \%$ & $-215.5 \%$ \\
\hline 分解 3 & & & & \\
\hline 実際值 $=0.148$ & 0.155 & -0.005 & -0.002 & $-0.7 \%$ \\
\hline 合計 $=100 \%$ & $104.6 \%$ & $-3.1 \%$ & $-1.5 \%$ & $-4.6 \%$ \\
\hline 各要因の寄与度 & & & & \\
\hline 教育年数 & $88.0 \%$ & $160.5 \%$ & $66.6 \%$ & $315.1 \%$ \\
\hline 経験年数 & $2.8 \%$ & $18.2 \%$ & $6.9 \%$ & $27.9 \%$ \\
\hline 党員 & $4.3 \%$ & $0.4 \%$ & $1.2 \%$ & $5.9 \%$ \\
\hline 男性 & $-8.4 \%$ & $-6.3 \%$ & $-7.0 \%$ & $-21.7 \%$ \\
\hline 既婚 & $-0.9 \%$ & $-15.6 \%$ & $-0.9 \%$ & $-17.4 \%$ \\
\hline 健康 & $-5.3 \%$ & $-3.2 \%$ & $-13.7 \%$ & $-22.2 \%$ \\
\hline 転職あり & $0.4 \%$ & $-21.5 \%$ & $-13.0 \%$ & $-34.1 \%$ \\
\hline 産業 & $23.7 \%$ & $-8.8 \%$ & $-7.6 \%$ & $7.3 \%$ \\
\hline 定数項 & $0.0 \%$ & $-127.0 \%$ & $-34.1 \%$ & $-161.1 \%$ \\
\hline
\end{tabular}

注) Oaxaca and Ransom(1994) モデルを用いた計測. 出所 : 表 1 と同じ.

正規部門においても，労働者が持つ戸籍により労 働市場が分断されているという新たな発見が得ら れた.

第 3 に，部門間格差の要因を検討する。（1）都 市正規と都市非正規間の所得格差については，所 得格差への寄与度は非属性格差が53.02\%で属性 格差 (46.98\%) より大きい. また，属性格差にお いて，寄与度は教育年数が $23.73 \%$ で最も大きく， 次いで産業が $14.70 \%$, 党員が5. 32\%である. 非属 性格差において, 経験年数が $26.14 \%$ で最も大きく, 次いで既婚が $6.13 \%$ となっている。（2）出稼ぎ正 規と出稼ぎ非正規間の所得格差については, 所得 格差への寄与度は分解 1 （人的資本モデル）の場 合，非属性格差が $61.4 \%$ で属性格差 (38.6\%) よ り大きく, また分解 2 (「人的資本十政治資本」モ デル）の場合，非属性格差が58.2\%で属性格差 
表7ー（1） 部門間格差に関する要因分解 （都市正規と都市非正規）

寄与度 : \%

\begin{tabular}{|c|c|c|c|c|}
\hline \multirow{2}{*}{$\begin{array}{l}\text { 都市戸籍住民 } \\
\text { 正規部門と } \\
\text { 非正規部門 }\end{array}$} & \multirow{2}{*}{$\begin{array}{l}\text { 属性格差 } \\
\text { (1) }\end{array}$} & \multicolumn{3}{|c|}{ 非属性格差 } \\
\hline & & \begin{tabular}{|l|} 
正規者の利得 \\
(2)
\end{tabular} & $\begin{array}{l}\text { 非正規者の損失 } \\
\text { (3) }\end{array}$ & $\begin{array}{r}\text { 合計 } \\
\text { (2) }+ \text { (3) }\end{array}$ \\
\hline 分解 1 & & & & \\
\hline 実際值 $=0.618$ & 0.200 & 0.066 & 0.352 & 0.418 \\
\hline $\begin{array}{l}\text { 合計 }=100 \% \\
\text { 各要因の寄与度 }\end{array}$ & $32.4 \%$ & $10.7 \%$ & $56.9 \%$ & $67.6 \%$ \\
\hline 教育年数 & $30.7 \%$ & $-30.9 \%$ & $24.6 \%$ & $-6.3 \%$ \\
\hline 経験年数 & $1.7 \%$ & $-9.1 \%$ & $36.9 \%$ & $27.7 \%$ \\
\hline 定数項 & $0.0 \%$ & $50.7 \%$ & $-4.5 \%$ & $46.2 \%$ \\
\hline 分解 2 & & & & \\
\hline 実際値 $=0.618$ & 0.223 & 0.063 & 0.333 & 0.395 \\
\hline $\begin{array}{l}\text { 合計 }=100 \% \\
\text { 各要因の寄与度 }\end{array}$ & $36.0 \%$ & $10.2 \%$ & $53.8 \%$ & $64.0 \%$ \\
\hline 教育年数 & $27.7 \%$ & $-25.5 \%$ & $13.5 \%$ & $-12.0 \%$ \\
\hline 経験年数 & $1.5 \%$ & $-5.7 \%$ & $30.1 \%$ & $24.4 \%$ \\
\hline 党員 & $6.8 \%$ & $-2.4 \%$ & $0.7 \%$ & $-1.6 \%$ \\
\hline 定数項 & $0.0 \%$ & $43.8 \%$ & $9.5 \%$ & $53.3 \%$ \\
\hline 分解 3 & & & & \\
\hline 実際値=0.618 & 0.290 & 0.052 & 0.276 & 0.328 \\
\hline $\begin{array}{l}\text { 合計 }=100 \% \\
\text { 各要因の寄与度 }\end{array}$ & $47.0 \%$ & $8.4 \%$ & $44.6 \%$ & $53.0 \%$ \\
\hline 教育年数 & $23.7 \%$ & $-25.0 \%$ & $0.7 \%$ & $-24.4 \%$ \\
\hline 経験年数 & $1.5 \%$ & $-4.6 \%$ & $30.7 \%$ & $26.1 \%$ \\
\hline 党員 & $5.3 \%$ & $-2.0 \%$ & $0.5 \%$ & $-1.5 \%$ \\
\hline 男性 & $1.3 \%$ & $-2.1 \%$ & $-6.7 \%$ & $-8.8 \%$ \\
\hline 既婚 & $0.3 \%$ & $1.5 \%$ & $4.7 \%$ & $6.1 \%$ \\
\hline 健康 & $0.0 \%$ & $-1.2 \%$ & $-4.8 \%$ & $-6.0 \%$ \\
\hline 転職あり & $0.1 \%$ & $-0.1 \%$ & $-0.8 \%$ & $-1.0 \%$ \\
\hline 産業 & $14.7 \%$ & $-2.1 \%$ & $-19.1 \%$ & $-21.2 \%$ \\
\hline 定数項 & $0.0 \%$ & $44.1 \%$ & $39.5 \%$ & $83.6 \%$ \\
\hline
\end{tabular}

注) Oaxaca and Ransom(1994) モデルを用いた計測. 出所 : 表 1 と同じ.

（41.8\%）より大きい.一方，人的資本，政治資本 以外の要因を含む分解 3 の場合, 属性格差が 113. 53\%で非属性格差（-13.53\%）より大きい. これらの分解結果により，人的資本と政治資本以 外の要因（例えば，産業など）が出稼ぎ正規と出 稼ぎ非正規間の所得格差に大きな影響を与えるこ とが示された。（3）属性格差において，寄与度は 産業が $75.07 \%$ で最も大きく, 次いで教育年数が $50.54 \%$ で大きい，非属性格差において，既婚が $209.55 \%$, 教育年数が $200.01 \%$ で大きく, 次いで 産業が33.95, 党員が14.85\%となっている.

異部門間格差の要因分解の結果によると, 以下 のことがわかった。（1）都市戸籍住民および出稼 ぎ労働者において, 教育水準と産業分布の差異, および教育収益率の差異が非正規部門と正規部門 間の所得格差の主な要因である。また所得格差に
表7－（2） 部門間格差に関する要因分解 （出稼ぎ正規と出稼ぎ非正規）

\begin{tabular}{|c|c|c|c|c|}
\hline \multirow{2}{*}{$\begin{array}{l}\text { 出稼ぎ労働者 } \\
\text { 正規部門と } \\
\text { 非正規部門 }\end{array}$} & \multirow{2}{*}{$\begin{array}{l}\text { 属性格差 } \\
\text { (1) }\end{array}$} & \multicolumn{3}{|c|}{ 非属性格差 } \\
\hline & & \begin{tabular}{|l|} 
正規者の利得 \\
(2) \\
\end{tabular} & \begin{tabular}{l|} 
非正規者の損失 \\
(3)
\end{tabular} & $\begin{array}{r}\begin{array}{r}\text { 合計 } \\
\text { (2) }+ \text { (3) }\end{array} \\
\end{array}$ \\
\hline 分解 1 & & & & \\
\hline 実際值 $=0.067$ & 0.026 & 0.036 & 0.005 & 0.041 \\
\hline $\begin{array}{l}\text { 合計 }=100 \% \\
\text { 各要因の寄与度 }\end{array}$ & $38.6 \%$ & $53.5 \%$ & $7.9 \%$ & $61.4 \%$ \\
\hline 教育年数 & $73.2 \%$ & $216.9 \%$ & $39.2 \%$ & $256.1 \%$ \\
\hline 経験年数 & $-34.6 \%$ & $-161.1 \%$ & $-62.1 \%$ & $-223.2 \%$ \\
\hline 定数項 & $0.0 \%$ & $-2.4 \%$ & $30.8 \%$ & $28.5 \%$ \\
\hline 分解 2 & & & & \\
\hline 実際值 $=0.069$ & 0.029 & 0.035 & 0.005 & 0.040 \\
\hline 合計 $=100 \%$ & $41.8 \%$ & $50.9 \%$ & $7.3 \%$ & $58.2 \%$ \\
\hline 各要因の寄与度 & & & & \\
\hline 教育年数 & $70.6 \%$ & $204.9 \%$ & $35.5 \%$ & $240.5 \%$ \\
\hline 経験年数 & $-33.5 \%$ & $-157.2 \%$ & $-61.3 \%$ & $-218.5 \%$ \\
\hline 党員 & $4.7 \%$ & $-1.2 \%$ & $0.3 \%$ & $-0.9 \%$ \\
\hline 定数項 & $0.0 \%$ & $4.4 \%$ & $32.8 \%$ & $37.1 \%$ \\
\hline 分解 3 & & & & \\
\hline 実際值 $=0.076$ & 0.086 & -0.009 & -0.001 & -0.010 \\
\hline $\begin{array}{l}\text { 合計 }=100 \% \\
\text { 各要因の寄与度 }\end{array}$ & $113.5 \%$ & $-11.8 \%$ & $-1.7 \%$ & $-13.5 \%$ \\
\hline 教育年数 & $50.5 \%$ & $173.5 \%$ & $26.5 \%$ & $200.0 \%$ \\
\hline 経験年数 & $-24.1 \%$ & $-506.6 \%$ & $-118.4 \%$ & $-625.1 \%$ \\
\hline 党員 & $1.7 \%$ & $0.9 \%$ & $0.1 \%$ & $1.1 \%$ \\
\hline 男性 & $11.7 \%$ & $13.1 \%$ & $1.7 \%$ & $14.9 \%$ \\
\hline 既婚 & $-1.3 \%$ & $179.0 \%$ & $30.5 \%$ & $209.5 \%$ \\
\hline 健康 & $-0.9 \%$ & $-118.8 \%$ & $-21.6 \%$ & $-140.5 \%$ \\
\hline 転職あり & $0.9 \%$ & $15.3 \%$ & $0.9 \%$ & $16.2 \%$ \\
\hline 産業 & $75.1 \%$ & $23.2 \%$ & $10.7 \%$ & $34.0 \%$ \\
\hline 定数項 & $0.0 \%$ & $208.6 \%$ & $67.8 \%$ & $276.4 \%$ \\
\hline
\end{tabular}

注） Oaxaca and Ransom(1994) モデルを用いた計測. 出所 : 表 1 と同じ.

与える影響は人的資本が政治資本より大きい. (2) 非属性格差が所得格差に寄与し，正規と非正規の 就業形態によって教育収益率の差異が存在するこ とが確認された。都市労働市場は, 正規部門と非 正規部門により分断されていることが検証された.

\section{5 おわりに}

本稿では, 中国における都市労働市場の分断化 の問題について, 先行研究とは異なる都市正規, 都市非正規, 出稼ぎ正規, 出稼ぎ非正規の 4 つの グループ間の所得格差に関する実証分析を行った. 所得格差に関する分析結果により, 中国では都市 労働市場の多重構造が存在し, 都市労働市場が戸 籍および就業する部門により分断されていること が検証された。 実証分析から得られた主な結論は 以下の通りである。 
第 1 に, 所得格差は, 都市正規と出稼ぎ正規, 都市正規と出稼ぎ非正規が都市非正規と出稼ぎ非 正規，出稼ぎ正規と出稼ぎ非正規より大きい。都 市正規者の夕国有部門の労働雇用・賃金制度の下 に優遇されていることがうかがえる.

第 2 に，正規部門および非正規部門のいずれに おいても労働者が持つ戸籍(農村戸籍と都市戸籍) によって人的資本と政治資本に対する評価の差異 が存在することが確認された，すなわち，都市労 働市場が戸籍制度により分断されていることが示 された. とくに正規部門においても労働者が持つ 戸籍により労働市場が分断されているという新た な発見が得られた.

第 3 に, 都市戸籍住民においても, 出稼ぎ労働 者においても，正規と非正規の就業部門によって 人的資本を含む各要因に対する評価が異なること が明らかになった。非正規部門と正規部門におけ る労働雇用・賃金制度が異なり，都市労働市場は 非正規部門と正規部門により分断されていること が示された.

第 4 に, 部門内格差, 部門間格差への寄与度は, いずれについても人的資本が政治資本より大きい. 各グループ間の所得格差に与える影響は, 人的資 本が政治資本より大きい.

以上の実証分析の結果から, 以下のような政策 上の示唆が考えられる.

第 1 に，本稿では非正規部門および正規部門い ずれにおいても労働市場が農村住民と都市住民の 戸籍により分断されていることが明らかになった. 労働移動を促進するため, 今後は戸籍身分により 労働雇用・賃金制度上差別的取扱いがなされてい るという問題を重視し, 出稼ぎ労働者と都市戸籍 住民に対する雇用均等法の設定・実施を検討す心゙ きである。

第 2 に, 都市労働市場は, 非正規部門と正規部 門により分断されていることは明確である。また 都市正規者と他のグループ間の格差が大きいこと が示された。これらの分析結果が得られた主な理 由は，非正規部門と正規部門とでは企業所有制が 異なるため，それぞれの賃金決定のメカニズムが 異なることにあると考えられる. 具体的にいえば, 正規部門では多くの労働者が国有部門 (国有企業, 政府機関など）で働いている一方，非正規部門で
は労働者の大多数が非国有部門 (外資企業, 民営 企業，個人企業など）で就業している. 国有部門 は計画経済期の賃金決定制度の影響を受け，賃金 の多くの部分が政府によって決定されている。一 方，競争市場に直面している非国有部門において は, 賃金水準が市場原理によって決定される（邢, 2007; 馬，2009b).中国における非正規部門と正 規部閒間の所得格差の問題を解決するため, 国有 部門のコーポレート・ガバナンスの改革を促進す ると同時に, 都市正規者のみを優遇する労働雇 用・賃金制度の改革が求められる. 公務員賃金制 度, 国家幹部 ${ }^{19)}$ の賃金制度の改革は今後の課題と なっている.また非正規部門の労働者の所得を高 める政策も必要である. 非正規就業者向けの職業 教育訓練制度, 最低賃金制度や自営業者援助政策 の実施を検討すべきである.

（慶應義塾大学産業研究所）

\section{[謝辞]}

本稿を執筆するにあたり, 北京師範大学経済と 工商管理学院の李実教授から2002年中国都市戸籍 住民家計所得調查および2002年中国出稼ぎ労働者 家計所得調査の個票データを提供して頂いた. 本 誌の匿名レフェリー, 日本大学村上直樹教授から は多くの有益なコメントを頂いた. 記して深く感 謝の意を表したい. 残る誤りはすべて筆者の責任 に帰する。

\section{注}

1）本稿で出稼ぎ労働者は，農村戸籍を持って都市で 就業する労働者と定義する.

2）非正規部門（informal sector）の定義については, ILO（1972）によれば，非正規部門は以下のような特徽 を持つ.つまり（1）参入しやすいこと，(2）原材料に 依存すること，(3) 露天商売や家族企業が多いこと，(4) 企業規模が小さいこと, (5) 労働集約型生産であること, (6) 外部の正規部門（formal sector）から技術を獲得する こと，(7) 競争市場に直面することの 7 点である. それ に対して, 非正規部門以外の市場を正規部門と呼ぶ. 本 稿では, 非正規者は非正規部門で就業する労働者, 正規 者は正規部門で就業する労働者を指す. 非正規と正規の 分類に関する詳しい説明については, 第 3 節 3.2 「用い たデータおよび変数設定の説明」を参照されたい．

3）労㗢市場の分断化理論については, Piore（1970） は「二重労働市場の仮説」(Dual labor markets) を唱えて いる.つまり高い安定性, 高賃金と良い労働環境を特徵 
とする第一次労働市場 (primary market) と, 不安定, 低 い賃金と劣悪な労働環境を特徵とする第二次労働市場 (secondary market）が併存することを指摘している. Dickens and Lang（1985）は，アメリカの都市労働市場に おいて第二次労働市場では，人的資本が重視されず，賃 金が低いため, 出稼ぎ労働者, 女性, 少数民族などの周 辺労働者しか第二次労働市場で就業しないことを示し ている.

4）本稿で都市戸籍住民は, 都市戸籍を持つ労働者と 定義する.

5）厳密にいえば, 正規雇用者，非正規雇用者の勤労 所得が「賃金」と呼ばれ, 自営業者の勤労所得が「所得」 と呼ばれる. 以下では記述の便宜上, 各グループの勤労 所得をすべて「所得」と呼び，各グループ間の勤労所得 の格差をすべて「所得格差」と略称する.

6）本稿では，同一部門における異なるグループ間の 所得格差は，出稼ぎ正規と都市正規間の所得格差，出稼 ぎ非正規と都市非正規間の所得格差を意味する.

7）本稿では，同一グループにおける異なる部門間の 所得格差は, 出稼ぎ正規と出稼ぎ非正規間の所得格差, 都市正規と都市非正規間の所得格差を意味する.

8）馬（2009a）は市場化改革の進展とともに，政治 資本と人的資本のいずれもが中国既婚女性の就業に与 える影響が大きくなったことを示している，また，周・ 図・摩（2002）は政治資本としての党員身分が労働者の 就業, 所得および社会地位に影響を与えることを指摘し ている.

9）本稿では，第一段階の推定で就業形態の選択に関 する多項プロビットモデルを用いる主な理由は, 以下の 2 点である. 第 1 に, サンプル・セレクション・バイア スの問題に対応寸るため, ヘックマンの二段階の推定法 (Heckman, 1976) を用いる分析が行われる方法がある. しかし, 本稿では第一段階の選択関数は, ヘックマンの 二段階推定法で就業するかどうかという二次元の選択 関数ではなく, 正規就業, 非正規就業, 非就業の 3 つの 選択肢から就業形態を選択する確率関数（多次元の選択 関数) である. そのため, 第一段階の推定で, ヘックマ ンの二段階推定法における二次元のプロビット分析モ デルではなく, 多元離散型選択モデルを用いることが必 要である. 第 2 に, 多元離散型選択モデルにおいて, 多 項ロジットモデルと多項プロビットモデルがある. ただ し，バイアスを修正する方法としては，第一段階，第二 段階の誤差項が bivariate normal に分布すること（もしく は，第一段階の誤差項の分布が正規分布であること）を 仮定することは前提条件である. 誤差項の正規分布の仮 定を満たすため，第一段階で多項プロビットモデルを用 いる分析は適切な方法であると考えられる.この点につ いては, 本誌の匿名レフェリーからは非常に有益なご助 言を頂いた。ここで感謝の意を申し上げる.

10）本稿では, 記述の簡素化のため, 推定式におけ る定数項の表示を省略している.

11）以下では，記述の簡素化のため，推定式におけ る定数項および添字 $i$ の表示を省略している.

12）ここで，厳密にいえば，非属性格差は，各要因
に対する評価の差異（例えば，差別的取扱い）とここで の説明変数ではとらえきれない部分に起因する格差の 両方を含むものであることに留意されたい.

13）計量分析では，説明変数における多重共線性の 問題が存在する可能性がある. 多重共線性の問題に対応 するため, 本稿で用いた各説明変数の相関関係を計算し た結果，相関係数はすべて 0.3 以下で小さいことが確認 された.

14）本稿では, 教育年数をそのまま説明変数に用い ており, 教育内容を区別していない.ここで教育年数が 同じでも, 教育内容の異なる可能性が存在することを留 意しておく. 例えば, 教育年数が 9 年間の場合, 中学卒 者と中等専門学卒の両方の可能性が存在し, また教育年 数が 12 年間である場合, 高校卒と高等専門学校卒の両方 の可能性がある. 学校教育の効果をとらえるためにその 内容を反映した学歴ダミーを用いることも考えられる が, 本稿では学歴ダミーではなく, 教育年数を用いる理 由は以下の通りである. 第 1 に, 人的資本の影響（例え ば, 教育の収益率など）を定量的に計測するため, Mincer （1974）は賃金関数の推定（標準なミンサー型の賃金関 数）で教育年数を説明変数としてそのまま用いている. 本稿では, 人的資本の影響を考察するため, 標準的ミン サ一型の所得関数を推定しており, これらの推定結果に 特に大きな問題はないと考えられる. 第 2 に, 所得格差 に関する要因分解の推定結果は用いるダミー変数によ って異なる. ダミ一変数の定義にともなう染意性によっ て要因分解のバイアスが起きる問題を回避するため, 本 稿では学歴ダミーを使用せず，教育年数を用いている.

15）経験年数は「年齢 -7 -教育年数」のように算出 した.

16) Mincer (1974), 小野 (1989), Gustafsson and Li (2000), Meng (2001), 馬 (2008a；2009b; 2009c), 㛜 (2008) は, 所得関数で教育年数 (あるいは学歴), 経験 年数（あるいは年齢）を用いている. 小野 (1989), 佐 藤（2003）は，所得関数で勤続年数を用いている. 本稿 では正規部門とくに国有企業における年功賃金制度の 影響を考察するため, 経験年数を説明変数として用いて いる.

17）他には，教育訓練（Meng，2001；馬，2008a）, 企業経営状況 (Gustafsson and Li, 2000), 地域 (Gustafsson and $\mathrm{Li}$ ，2000）が所得に影響を与えると考えられるが, UCHIP 2002および MCHIP 2002において, これらの情報 を取得することができないため, 本稿の計量分析ではこ れらの要因を説明変数として用いていない. これらの要 因を含むより包括的な分析は今後の課題としたい.

18）表 5 で逆ミルズ比を求めるため，第一段階で多 項プロビットモデルを用いた分析を行った. これらの分 析結果を表3でまとめている．誤差項の相関関係を示す 各変数（atrho21, atrho23, atrho13）の推定值によると, 都市労働者, 出稼ぎ労働者において, いずれも選択関数 の各䛊差項はお互いに相関関係を持つことが示された.

19）中国では，国有部門で大卒以上の正規労働者は 「国家幹部」と呼ばれる. 国家幹部の賃金水準および人 事異動は，政府により決定される部分が多い。 


\section{参考文献}

[日本語文献］

小野旭（1989）『日本的雇用慣行と労働市場』東洋経済 新報社.

㛜善平（2008）「上海市における二重労働市場の実証分 析」『アジア経済』第49巻，第 1 号, pp. 2-24.

戸田淳仁・馬欣欣（2005）「若年時の転職がその後の賃 金に及ぼす影響」樋口美雄・慶應義塾大学経商連 携21世紀 COE 編『日本の家計行動のダイナミズ ム 1 一慶應義塾家計パネル調查の特性と居住・就 業・賃金分析』慶應義塾大学出版会, pp. 163-179.

馬欣欣 (2008a)「農村一都市の労働力流動と中国の都市 部における賃金格差 : 都市部の労働市場の分断化 に関する実証分析（上）（下）」『大原社会問題研 究所雑誌』第591号, pp. 39-51; 第592号, pp. 62-72.

馬欣欣 (2008b)「中国における雇用調整と再就職後の賃 金の男女格差」『日本労働研究雑誌』第571号, pp. 104-119.

馬欣欣 (2009a)「中国都市部における既婚女性の労働供 給の規定要因：1995年，2002年中国都市家計調査 に基づいて」『アジア研究』第 55 巻, 第 3 号, pp. 35-54.

馬欣欣（2009b）「市場経済期の中国における企業所有制 別賃金構造の変化 : 1995～2002」『中国経済研究』 第 6 巻，第 1 号, pp. 47-63.

馬欣欣 (2009c)「中国の都市部における男女間賃金格差 の変化およびその規定要因 : 1995年，2002年都市 家計調査の個票データによる実証分析」,『アジア 経済』第50巻，第 7 号, pp. 2-25.

[中国語文献］

蔡昉・王徳文（1999）「中国経済増長的可持続性与労働 貢献」『経済研究』第 10 期, pp. 62-68.

蔡昉・白南生編（2006）『中国転型時期労働力流動』北 京 : 社会科学文献出版社.

Knight • 李実 (2004)「中国城鎮職工失業的持続性与再就 業職工的収入」李実・佐藤宏編『経済転型的代価 一中国城市事業, 貧困, 收入差距的経験分析』中 国財政経済出版社.

李実 •丁丁赛 (2004)「中国城鎮教育収益的長期变動趨勢」 李実・佐藤宏編『経済転型的代価一中国城市事業, 貧困, 收入差距的経験分析』中国財政経済出版社.

宋麗娜・S. Appleton（2006）「中国労働力市場中有権益階 層与無権益階層的対抗：尋求就業与政府干涉」蔡 昉・白南生編『中国転型時期労働力流動』北京 : 社会科学文献出版社.

邢春水（2007）「経済転型与不同所有制部門的工資決定」 『管理世界』第 6 期, pp. 23-37.

岳澎 ・黄解宇 (2008) 「従 “二元結構” 到 “三元結構” 一中国農民工的戸籍演変路径及其方案」『農業現 代化研究』第29巻，第 2 号，pp. 134-137.

佐藤宏（2004）「外出務工謀職和城市労働力市場一市場 支撑機制的社会網絡分析」李実・佐藤宏編『経済 転型的代価一中国城市事業，貧困，收入差距的経
験分析』中国財政経済出版社.

周雪光 ・図瑪 • 摩恩 (2002)「国家社会主義制度下社会 階層的動態研究」辺燕杰編『市場転型与社会分層』 北京 : 三聯書社.

[英語文献]

Ashford, J. R. and R. R. Sowden (1970) Multi-variate Probit Analysis, Biometrics, Vol. 26, pp. 535-546.

Amemiya, T. (1981) Qualitative Response Models: A Survey, Journal of Economics Literature, Vol. 19, pp. 1483-1536.

Becker, G. S. (1964) Human Capital: A Theoretical and Empirical Analysis, with Special Reference to Education, New York: Columbia University Press.

Blinder, A. S. (1973) Wage Discrimination: Reduced Form and Structural Estimation, Journal of Human Resources, Vol. 8, pp. 436-455.

Cotton, J. (1988) On the Decomposition of Wage Differentials, Review of Economics and Statistics, Vol. 70, No. 2, pp. 236-243.

Dickens, W. and K. Lang (1985) The Reemergence of Segmented Labor Market Theory, America Economic Review, Vol. 78, No. 2, pp. 129-134.

Greene, W. H. (2003) Econometric Analysis, 5th ed., Upper Saddle River, N.J.: Prentice-Hall, pp. 931-933.

Gustafsson, B. and Shi Li (2000) Economic Transformation and the Gender Earnings Gap in Urban China, Journal of Population Economics, Vol.13, pp. 305-329.

Heckman, J. J. (1976) The Common Structure of Statistical Models of Truncation, Sample Selection and Limited Dependent Variables and a Simple Estimator for Such Model, Annals of Economic and Social Measurement, Vol. 5, pp. 475-492.

International Labor Organization (1972) Employment, Incomes and Equality: A Strategy for Increasing Productive Employment in Kenya, Geneva: ILO.

Knight, J., L. N. Song and H. B. Jia (1999) Chinese Rural Migrants in Urban Enterprises: Three Perspectives, in Cook, S. and M. F. Margaret (eds.) The Worker's State Meets the Market: Labor in China's Transition, London: Frank Cass.

Lees, F. A. (1997) Chinese Superpower: Requisites for High Growth, New York: St. Martin's Press.

Margaret, M. F. and N. Ngan (2004) Differential Rewards to, and Contributions of, Education in Urban China's Segmented Labor Markets, Pacific Economic Review, Vol. 9, No. 3, pp. 173-189.

Meng Xin (2001) The Informal Sector and Rural-Urban Migrant: A Chinese Case Study, Asian Economic Journal, Vol. 15, No. 1, pp. 71-89.

Mincer, J. (1974) Schooling, Experience and Earning, New York: Columbia University Press.

Neumark, D. (1988) Employer's Discrimination Behavior and the Estimation of Wage Discrimination, Journal of Human Resources, Vol. 23, pp. 279-295. 
Neumark, D. (2004) Does Marriage Really Make Men More Productive? in Neumark, D., Sex Differences in Labor Market, London: Routledge, pp. 29-48.

Oaxaca, R. L. (1973) Male-Female Wage Differentials in Urban Labor Markets, International Economic Review, Vol. 14, No. 3, pp. 693-709.

Oaxaca, R. L. and M. Ransom (1994) On Discrimination and the Decomposition of Wage Differentials, Journal of Econometrics, Vol. 61, pp. 5-21.

Piore, M. J. (1970) Job and Training, in S. H. Beer and R. Barringer (eds.), The State and the Poor, Cambridge,
MA: Winthrop, pp. 53-83.

Reimer, C. W. (1983) Labor Market Discrimination against Hispanic and Black Men, Review of Economics and Statistics, Vol. 65, No. 4, pp. 570-579.

Roberts, K. D. (2001) The Determinants of Job Choice by Rural Labor Migrants in Shanghai, Chinese Economic Review, Vol. 12, pp. 15-39.

World Bank (1996) The Chinese Economy: Controlling Inflation, Deepening Reform, Washington, D.C.: The World Bank Publication. 